Andreász Kosztopulosz - Éva Kuruczleki (eds.) (2020): The Challenges of Analyzing Social and Economic Processes in the 21st Century. University of Szeged Faculty of Economics and Business Administration, Szeged, https://doi.org/10.14232/casep21c.13

\title{
An in-depth survey of the factors causing dissatisfaction within the group of elderly workers in South Transdanubia
}

\author{
Gábor Hoványi - Róbert Tésits - Levente Alpek B.
}

The currently still active age group (aged 50-64) faces a number of difficulties with the approaching retirement age, as their ability to work and adapt quickly to changing situations are constantly losing their effectiveness. With this, of course, we do not claim that an older worker will carry out his or her work less effectively than a younger worker, as the experience gained in a particular job can balance out the performance differences stemming from age. However, as we approach the retirement age, losing your job at an older age would pose serious challenges for those who would want to return to the group of economically active workers. It is unlikely that they will find a job that matches their qualifications, as their knowledge is less up-to-date and employers would prefer young people who could be relied on in the longer term, as opposed to those who need to be replaced within a few years. These potential difficulties are revealed by the widely distributed questionnaire, which seeks to identify the motivations and preparedness of different social strata for the changing challenges of a precarious age, based on the current economic situation and living conditions of the workers.

Results: Through the questionnaire survey, we were able to gain insight into how aging workers are preparing for their approaching retirement years and what steps they can take to preserve their current labour market position, as well as what opportunities they might have for returning to the labour market after losing their jobs as a result of possible redundancies.

Conclusion: Due to the aging national age structure, the situation of the aging workers is becoming an increasingly widespread problem, which, if we are not able to remedy in time, then will have to count on the degradation of the employability for the examined group in the near future. This will be mainly due to the constantly deteriorating health status of the individuals and the overwhelmed health care system that needs to provide for all age groups.

Keywords: aging workers, economic situation, living conditions, retirement age, employability

\section{Introduction}

Today, the increasing number of people born in Hungary during the Ratkó era entering retirement is becoming an increasingly serious socio-economic problem, as the proportion of recipients of state benefits is continually increasing, while an increasing proportion of active earners belongs to the aging age group (50-64 years of age). It follows from this that the number of dependents will rise even higher within a short time, partly due to those reaching retirement age and to the aging workers becoming economically inactive, which will put an even greater burden on the social support capacity of the economy.

The increasing social and health contributions are just one of the many negative effects of the aging population pyramid of Hungary. This study does not address all the negative effects; it exclusively focuses on those that apply to the 50- 
64 year old active age group. Of these problems, the fast approaching retirement age is of primary importance, which puts the domestic economy in an almost insoluble situation. This in itself makes the problem urgent, but this is only the tip of the iceberg. In addition to mass retirement within a few years, another pressing problem is the decline in the adaptability of aging workers. A younger employee can more easily meet the ever-changing demands of the workplace. In addition to being less able to adapt to changing requirements, such as the use of digital technologies at the user level, their knowledge, acquired years ago or in worse case decades ago, is nowhere near up-to-date. An exception to this, of course, are the aging workforces, who are committed to lifelong learning and are constantly striving to improve their skills.

Therefore, after losing their job in old age, they have a minimal chance of returning to the labour market without help. In order to elucidate the problems of this age group, we attempted to survey the inhabitants of the favourable, intermediate and disadvantaged type settlements of Southern Transdanubia with a questionnaire survey, which spatial structure was assigned to us by the previously published rDSS-index (Hoványi-Tésits-Alpek 2019). Our aim is to shed light on connections that can complement our assumptions based on secondary statistical analysis, thus further identifying the source of the problems and suggesting possible ways to remedy them in the future. This general objective is pursued in the study through the following subobjectives. The focus of the study is to discover the skills and abilities of our target group as well as the diseases that prevent them from working, which are essential for their success in the labour market. Other goals include exploring the target group's current labour market position, exploring their future plans, and measuring their willingness to continue training. Last but not least, we would like to know the needs of the respondents and whether these can be satisfied with the social services currently available.

\section{Literature review}

In setting the boundaries of the 50-64 year old age group on which the questionnaire was based, the endpoint proved to be relatively simple, as we had to look back from the last active year before the current retirement age limit. However, determining the start of old age was far more difficult. Both the gradual deterioration of health status and reports based on public opinions suggested that the onset of aging is between the ages of 50 and 60 (Dobossy-S. Molnár-Virágh 2003), therefore in order to include all individuals affected by aging we extended the target group of the questionnaire to the Southern Transdanubians from the age of 50 to 64. The area of the survey is the Southern Transdanubian Region; based on the findings of the latest TÁMOP research, which examined the modernization of social services, turned out to be one of the three most underdeveloped regions of Hungary. This region is considered under developed in the sense of accessibility to these services as every region has enough service providers; however they are not equally available to everyone due to space-time constraints (Hernandez-Rossel 2015). One of the most notable difficulties of such disadvantaged regions is the delivery system of these services, which is rather problematic to achieve in minor settlements without the necessary vehicles and adequate road system (Bakri et al. 2016). 
Despite national funding not everyone receives adequate support therefore a more harmonic coexistence with nature is required for people in need to be able to meet their basic requirements (Augustine-Dolinting 2016). For the higher strata of society, this is not a problem, but as we move down the social pyramid, the number of people with social and livelihood problems increases exponentially. The increase of the differences between the social strata is not an isolated case, as the number of individuals, families and communities in need of assistance in every country of the world is growing. Many methods of assistance that are included in the collective concept of social services, which has been created to address these problems that the most disadvantaged members of society can use to improve their situation. While the pensioners have the financial background to access their requirements, families living in poverty cannot meet these so easily, therefore support must be ensured by child welfare services (Fong 2017). Although most elderly people may have serious health issues, which can have a negative effect on their social status and this needs to be compensated with state intervention (Jeon et al. 2017). Despite the fact that most elderly people may not have financial or health troubles, but those living in residential social services do have a major problem, which is depression that can greatly decrease the life quality of seniors (Jakešová 2015). The goal of the study is to gather soft information through the aforementioned questionnaire survey to give a more accurate picture of the Southern Transdanubian region in the sense of how big the target group is, where they are located and what are the services that they require to make the current social system up-to-date. This can greatly benefit policy makers in better handling the constantly changing requirements of society (Menachem 2015).

\section{Methods}

The present study is the result of a longer study in which we first addressed the issues related to the social welfare system, followed by an examination of the territorial distribution of people in need using statistical indicators. From the initial 34 indicators, we created the rDSS index using only 15 indicators, which brought the novelty of being able to categorize the South Transdanubian settlements into four groups based on the degree of their disadvantaged position. This has created a favourable, an intermediate, which can be further divided into more favourable and less favourable, and a lagging type of settlement where the reliance on social services is the highest. The categorization of these settlements was an indispensable step in the establishment of further surveys, whereas this provided the territorial sampling basis for the survey in the case of the 653 settlements of Southern Transdanubia.

The questionnaire survey addressed the population of the lagging, intermediate and favourable type settlements of the three counties forming the Southern Transdanubian Region - Baranya, Somogy and Tolna. 20.98\% of the settlements (137 settlements in total) belonged to the group of favourable-type settlements, mainly composed of the county seats and the settlements directly surrounding them. $67.07 \%$ of the settlements (438 settlements in total) belonged the group of intermediate-type settlements, which shows that the reliance on social services in the district headquarters is not obvious, especially due to the fact that more 
than half (239 settlements, 36,6\% of all settlements) are part of the group of more favourable intermediate position settlements. Fortunately, only $11.94 \%$ of the settlements (78 settlements in total) were included in the group of lagging-type settlements.

The questionnaire used in the primary data collection also asks for highsensitivity data, so it is extremely important that the questionnaire was voluntary and anonymous. The questionnaires were distributed in Hungarian and in paper format so that individuals without internet access could also fill it in. A total of 164 questions in the 10-page questionnaire cover the following topics. In addition to general socioeconomic issues, it examines the role of skills and abilities, the importance of living conditions and standards of living. It highlights the role of health, social relationships, future plans and opportunities from the perspective of the need for social services. It also reveals the labour market position, the working conditions of the family members, the willingness to continue training and retraining, and asks about the shortcomings in the care system as well as development opportunities.

The general questions ask only basic information such as place of residence, marital status, and number of dependents, all of which can help determine the level of individual need. In addition to the highest level of education, the skills and abilities section of the questionnaire covers foreign language skills and computer skills, which are nowadays a basic requirement for finding and retaining a job. The third chapter is intended to reveal the living conditions such as the type, size, equipment and comfort level of residential property, as well as difficulties in living and the degree of satisfaction with an individual's current standard of living. In the health section, we were not only curious about whether the respondents struggle with disease or addiction, but also about their observations about health care institutions a well as what they themselves do to maintain their health. Social relationships are extremely important in order to avoid the problem of old age isolation; therefore here we were searching for the causes of neglect. In the sixth chapter, we asked how consciously are planning their future and what they are doing to make it a reality. In the next set of questions, we were interested in the current labour market position of individuals and how many of the occupants also have jobs in the same property / household as the respondents. In terms of financial situation, we sought answers to the questions of how much the individual earns as well as the total income of household. The question group of continuing education and retraining provides an opportunity to gain insights into the individuals' labour market motivations and prospects. In the tenth group with the most questions, we asked about the needs related to social problems that are typical of this age group, and whether they knew of institutions or organizations in their area that might be able to remedy / alleviate these. The last two sets of questions were purely elaborative, asking about the shortcomings encountered by the respondents in accessing social services and their suggestions for improvements.

Among settlements selected for the questionnaire survey by the rDSS-index, there is of course at least one of each of the four settlement types, but despite the personal visit, due to the limited willingness to fill out the questionnaire, we failed to survey the population of all the settlements that we contacted. The empirical study is currently based on the results of 460 completed questionnaires. 
In terms of gender, the majority of the respondents to the questionnaire are women $(58.7 \%)$, while the men represent only $41.3 \%$. With regard to the place of residence, the urban population was overrepresented, as there was a greater willingness to fill out the questionnaires than in the villages. On the basis of age, only $8.7 \%$ of the respondents did not reach the age of 50 at the time of the survey, however, since their housing was solved only with state support, their inclusion in the study group was also considered relevant. $69.5 \%$ of the respondents do not live with dependents; most of them started their own lives, while the other respondents did not even have a child. An additional $30.5 \%$ of the respondents share their residential property with one to three dependents, most of whom are children, grandchildren and to a lesser extent other relatives. Exceptions to this are the recipients of subsidized housing services, who also belong to the target group of the study.

\section{Results}

\subsection{Labour market skills and competences}

In terms of skills and abilities that also determine the labour market position, the respondents range from an extremely wide scale, as we find respondents who have not even completed primary school education to those who have successfully completed a doctoral program. There is a similarly wide variation among the studied professions, therefore we can find teachers, kindergarten teachers, dealers, nurses, mechanics and administrators. Only $41.3 \%$ of the respondents have some degree of foreign language skill. However, just over one-quarter $(26 \%)$ of those completing the survey have one or two language exams, with Russian, English, German and French being the most common. The situation is very similar in the case of computer skills, where only the highly qualified can use the different softwares at a minimum user level, while the respondents with low skills have not acquire this knowledge.

Considering the territorial allocation of the respondents, it can be stated that most of them with the above mentioned skills expected by the labour market settled in the county seats and larger towns in order to obtain a better labour market position, while the respondents in villages do not have these qualities or only to a limited level. This gap mainly appears in the case of computer skills, as the slowly retiring industrial society is gradually being replaced by the information society, which has the skills that the labour market expects, but less than half of the older workers, according to questionnaires $(43.5 \%)$ are able to use information technologies at a minimum level (Nemeskéri - Szellö 2017). The number of labour market opportunities is in direct proportion to the size of the settlement, so it is not surprising for us that the place of residence determines the still active workforce, rather than having a high level of education and language exams. Highly educated young people living in rural areas will leave their homes and try to find jobs in the cities in hopes of better livelihoods and higher salaries, while those remaining in the villages as less educated and less willing to move. 


\subsection{The living conditions of the survey respondents}

Responses to quality of life questions indicate that less than half (45.6\%) of respondents are satisfied with their current living conditions, while less than $39.1 \%$ have smaller or bigger unmet needs. In almost all cases, respondents living in detached or terraced houses, even if they could, would not change their type of residential property and consider only the amount of available monthly budget insufficient. However, more than a tenth of the respondents $(10.8 \%)$ are not at all satisfied with their current living conditions, which is mainly due to the low level of amenities and insufficient financial resources. Respondents have a wide range of residential property types, ranging from a $40 \mathrm{~m}^{2}$ apartment to a $160 \mathrm{~m}^{2}$ detached house, while most respondents seem to be satisfied with the type of property available to them. Although it is also the case that those who live in a detached house would prefer to move into a condominium and those who live in an apartment want their own detached house. Overall, dissatisfaction causes a problem in the case of more than half of the respondents, but they do not want to change this state or they cannot. The general problem arises for those who want to move from a 40 to $70 \mathrm{~m}^{2}$ condominium or apartment to a detached house, which however is only possible in villages farther away from the big cities or holiday houses in need of a major renovation on the outskirts of the agglomeration. In the latter case, however, they would no longer have sufficient resources for renovation work, or in a more favourable case, they would not have time to carry out such work before retirement or have it done by professionals. Respondents who have experienced the many maintenance tasks associated with detached or terraced houses would like to move into residential properties that require less house work, such as condominiums, apartments or prefabricated homes, as retirement age approaches. They have the opportunity to do so from the value of their current real estate, unless these are located in a rural area far from the metropolitan area.

After processing the questionnaires, it cannot be clearly stated that individual settlements have a favourable or unfavourable impact on the living standard of the inhabitants on the basis of their position in the settlement hierarchy, but the level of equipment of different residential properties is closely related to the level of general satisfaction. The amenities of the real estates was surveyed by asking for 22 pieces of electrical equipment in order to provide an accurate picture of the comfort level of the occupants' properties, since asking the comfort level is the subjective judgment of the respondent, which is unlikely to coincide with the criteria used by the CSO. The electrical appliances include large household appliances (e.g. cooker, ceramic hob, gas or electric oven, microwave oven, refrigerator, washing machine and dishwasher), telecommunication equipment (e.g. internet, Wi-Fi, landline, cell phone, smartphone) or consumer electronics (e.g. TV, computer, laptop, Hi-Fi, home theatre system, game console) and air conditioners. The highest number of the equipment that respondents had in their households was 18 out of 22, and in the majority of cases with up to 15 items indicated that the residents were satisfied with their living conditions. It is worth noting that there were some respondents, who even with 17 devices were only partially or not at all satisfied with their living conditions. About $30.4 \%$ of the respondents have 10 or fewer of the devices listed above. Nevertheless, only half of this subgroup 
admitted that they were only partially or not at all satisfied with their living conditions due to the low number of assets. From this we can conclude that only in the case of 12 or more assets can equipment be a reliable indicator of satisfaction (Microcensus 2016).

\subsection{The general health status of the survey respondents}

As the health of workers continues to deteriorate with age, it is not surprising that only $13 \%$ of them admitted of being completely healthy. Almost half of the respondents $(45.6 \%)$ report minor health problems. Slightly more than one-tenth $(10.8 \%)$ struggle with the temporary deterioration of their state of health, and nearly one-third (30.4\%) have a permanent, chronic condition. Only $8.7 \%$ of respondents are dissatisfied with the quality of care provided by GPs, clinics and hospitals, but the majority of respondents are satisfied with the quality of domestic health services. With the exception of nine respondents, everyone noted that preserving health, conscious nutrition and regular exercise is important, however $46.5 \%$ of the respondents regularly drinks alcohol and $26 \%$ smoke. These values may cause serious concern, as the deterioration of health with age may contribute to a significant reduction in elderly activity.

$30.4 \%$ of respondents said they had a long-term illness, and that this was mostly caused by their unhealthy lifestyle and severe stress at work, regardless of their place of residence in the settlement hierarchy. Indeed, some people living in rural areas struggle with poor health, but more active outdoor life can compensate for the lack of heath service, while widespread health care can balance out the poorer health associated with urban stress. All in all, we see in the results that urban populations gave a poorer assessment of the health care systems than those living in rural areas. Gender distribution proved to be a better indicator than the place of residence, as while $47.4 \%$ of the surveyed men had a long-term illness, this was only true for $18.5 \%$ of women, which is similar to the CSO data, which also supports the higher life expectancy of women. This, in turn, leads to a shift in the gender ratio of old age, which will increase the number of elderly women living alone, who, even from their age, are more burdened by daily tasks than elderly men (S. Molnár 2004). Almost all respondents considered it important to preserve their state of health, but when asked what they were doing to achieve this; we received only few valuable answers. Overall, $58.7 \%$ of the respondents provided an answer, however most of these gave us the impression that these respondents do not know how to make the first step towards a healthier lifestyle. There are three possible causes of this phenomenon, the decline in economic activity and income as well as the decline in social relationships, all of which go hand in hand with aging (S. Molnár 2006). The latter finding is supported by the fact that more than one-third (34.8\%) of those completing the questionnaire live alone and that there is no specific person for them to support or to assist them. This will eventually lead to a decrease in their general demand levels. All of these contribute to the deterioration of their health. 


\subsection{Social relationships}

In the case of social relations, only $21.7 \%$ of the respondents would use help in their daily lives, which is a good result, considering that nearly $9 \%$ more have a longstanding illness and are still not dependent on their relatives or their surroundings for support. Most respondents rarely meet with their relatives, friends and acquaintances, but only $23.9 \%$ would change their current social relationships. Interestingly, $28.3 \%$ of all respondents lack emotional care in their lives, which outnumbers both those seeking help and those willing to change their social life. All of this highlights the problem of isolation and also predicts an increase acceptance of this tendency.

The inhabitants of villages and small settlements, because of their immediacy, are much more helpful to each other and even to strangers, than the inhabitants of cities and county seats. Individuals' marital status can be a good starting point for us, as $63.6 \%$ of respondents are single or divorced, which can make life very difficult at an older age when there is no one to rely on or interact with on a daily basis. The educational attainment of those completing the study is more differentiating than the place of residence, as $81.8 \%$ of those who need help have only a high school education or less. The remaining $18.2 \%$ may even have a university degree, so it is not only this or being single that determines whether or not someone needs the assistance of others. In our opinion, active lifestyles can be the key to maintaining an independent selfsustaining life despite old age (Majercsik 2004), which is independent of the type of the place of residence, but can still be greatly influenced by education and support from the immediate family.

As the retirement age approaches and the younger members of the family become more independent, this contributes to the continuing decline in occupational activity. It is natural for aging workers to perform less and less tasks as they get older. The loss of caring for the family and the other shortcomings mentioned above all add to the increased risk of social isolation, which, in the absence of external motivation, is becoming an increasingly serious problem among currently still active workers (Szemán et al. 2007).

\subsection{The future preferences of the survey respondents}

The main observation from the answers given in the plans and opportunities group of questions is that the majority of respondents $(58.6 \%)$ have specific financial goals for the near future, but only $47.8 \%$ have some kind of retirement savings. However, an additional $47.8 \%$ of the respondents have no savings and only $6.5 \%$ would start saving money in order to fulfil their future plans and provide for their elderly care. There are some people who have been paying attention to the importance of saving up money for a long time, even 15 to 20 years, but this amount depends on many factors. Based on the received responses, the amount of monthly savings falls between 3 and 25 thousand HUF, which is mostly determined by the minimum salaries corresponding to the qualification level of the individuals. Saving money, despite the amount, is important not only because it guarantees financial security for a calm old age, but it also carries spiritual gains. 
The vast majority $(84.2 \%)$ of respondents, who do not have plans for the future live in a county seat or a large metropolitan area. Despite the fact that $63.2 \%$ of this group of respondents live in detached or semi-detached houses and only $36.8 \%$ live in condominiums or apartments. There is a slight shift in gender distribution, $57.9 \%$ of women and only $42.1 \%$ of men.

\subsection{Socio-economic position}

As with educational qualifications, respondents hold a variety of different labour marker positions, with the majority in this study having only a high school graduation or secondary qualification (63\%). Slightly more than one third $(34.8 \%)$ of the respondents have at least tertiary qualification or even higher educational attainment. In spite of their higher education and the resulting better socio-economic status, $37.5 \%$ of these respondents are only partially satisfied and $6.3 \%$ are not at all satisfied with their current living situation because their monthly salary is not sufficient to meet their targeted standard of living. The responses to the questionnaires showed that only $10.8 \%$ were not at all satisfied with their current job, even though they reportedly had the opportunity to change jobs. Although half of the respondents believe that they will be able to return to work after losing their current job, $54.3 \%$ of respondents would be more severely affected by the loss of their job, which could indicate a high degree of insecurity among aging workers.

$19.6 \%$ of all respondents who are partially or completely dissatisfied with their jobs are in the vast majority of cases employed in county seats or surrounding big cities, and only $11.2 \%$ live in rural areas. It may come as a surprise to us that one third of these respondents $(33.3 \%)$ have at least tertiary education and a good labour market position, but are not satisfied with their job. From this we can conclude that the level of education is less decisive for job satisfaction than the place of residence. However, gender proved to be a better indicator, as the proportion of women in this group of respondents $(66.7 \%)$ was twice that of men $(33.3 \%)$.

Nearly two-thirds $(65.2 \%)$ of the respondents would be slightly or very indisposed to lose their job despite the fact that one-third $(33.3 \%)$ of these respondents had tertiary education or even higher educational attainment. In spite of the fact that the vast majority of these workers live in large cities where they have much more job opportunities than the residents of rural areas. There is a shift in the gender ratio, as the loss of a job would shake men less, as the majority $(60 \%)$ of the respondents were women. This is partly due to the fact that $23.3 \%$ of these female respondents are single, which in itself makes it difficult for them to sustain themselves and raise their children, so they will be particularly affected by the loss of their jobs.

\subsection{The financial situation of the survey respondents}

Concerning the financial and income situation, $32.6 \%$ of the respondents stated that they either have no difficulties at all or are able to make smaller savings. Only $17.4 \%$ of respondents live up their whole salary and the remaining $15.2 \%$ are unable to make do with the money they receive in one month. Therefore they have to make up for the shortfall from loans, which in the long run could lead to total debt and eventually 
eviction. The amount of salaries supports the above-mentioned livelihood problems, as $10.8 \%$ of the respondents do not even earn 80 thousand HUF a month, and the income of $21.7 \%$ of the respondents does not reach 110 thousand HUF a month. Of course, earnings below 80 thousand HUF are due to the fact that they are not full-time employees. This means that more than a fifth of the respondents are earning below or just above the minimum wage, which in 2019 was a net 99,085 HUF. Almost half of the respondents (45.6\%) earn between 110 thousand HUF and 200 thousand HUF per month, and more than a quarter (26\%) of all respondents earns less than 150 thousand HUF per month. Monthly net earners between 200 and 300 thousand HUF make up $17.3 \%$ of all the respondents who have no livelihood problems, as do $6.5 \%$ who take home more than 350 thousand HUF a month. The minimum amount for which workers are willing to go to work is the same as the current minimum wage, but there are also glaring cases where employees want to earn up to six times that amount, which is unrealistic for certain qualifications. However, according to the questionnaires, there are households where the total income can reach up to 600 or even 800 thousand HUF per month. Men seem to be in a better financial position in terms of gender, as $85.7 \%$ of the respondents in this group are women.

The respondents' financial status can only be interpreted as subjective wellbeing (Hajdu 2015), that is, whether one considers his or her own standard of living to be satisfactory or insufficient. Based on the multiple-choice questions of the questionnaire, we can highlight the subjective well-being of the respondents and compare them with their residential appliances to determine their consumption preferences. $32.6 \%$ of all respondents felt that their financial situation was insufficient for self-preservation or only sufficient for that. However, it is worth mentioning that one fifth of these respondents live in $90 \mathrm{~m}^{2}$ real estates and more than half of them $(53.3 \%)$ have eleven or more household items, as detailed above. This leads us to conclude that although the individual may have a good financial position in an objective sense, but according to his or her subjective judgment, does not consider it sufficient.

\subsection{Training and retraining potential}

Based on the responses given to the questions concerning learning and continuing training, nearly two-thirds $(63 \%)$ of those surveyed, while satisfied with their current job, would still undertake further training to gain a better position within the workplace. This kind of advancement may be related to preparing for retirement, because the higher position they reach, the higher their salary base will be from which they calculate their later pension. In the absence of motivation, only $21.7 \%$ of the respondents rejected the possibility of further training, despite the fact that most of them considered themselves able to acquire new knowledge. The willingness for retraining is already much lower, which only $36.9 \%$ of the respondents would undertake. At this age, the likelihood of a major change in professional orientation is low. However, half of the respondents clearly rejected retraining as an opportunity for advancement, despite the fact that the majority would consider themselves suitable for acquire a new profession. This is partly due to a lack of motivation and partly due 
to lack of time given for training, which may also reflect employers' inflexibility in career development.

Of the factors analysed above, living conditions, health, labour market position and financial situation have proved to be the most decisive factors in judging living conditions. The majority of the respondents are dissatisfied with the type of property they are currently living in because they either find it too big and no longer need it, or on the contrary, want bigger one. Dissatisfaction with residential properties can result from an individual's health condition, which appears to be the most serious problem, as if this altered condition may prevent the individual from working, it may also have a serious impact on his or her self-preservation ability during retirement. The majority of respondents would also like to get a better job in the case of labour market position, but lack the motivation and confidence to take the first step. Last but not least, almost every individual who filled out the questionnaire wants to achieve a better financial situation for himself/herself or his/her family. These show us that the most important social services that this age group would need are motivational training, career planning and financial advice to be able to fulfil their future plans. Increasing the capacity of nursing homes and care homes for those with poor health could contribute to reducing future overload.

\subsection{Social needs and vulnerability}

Depending on age characteristics, this age group needs little assistance from social welfare institutions, despite the fact that $60.8 \%$ of respondents have access to information on various services and only $18.3 \%$ are unaware of the fact that their municipality has institutions specialized for such services. However, almost one third $(32.6 \%)$ of the respondents have no information about their existence, which shows that the necessary information is not available to everyone. Most surprising is that, none of the respondents answered that they would use social services, whether they were aware of them or not. In addition, more than a quarter $(28.2 \%)$ clearly refused to use social services. This may be partly due to the low level of awareness and the fact that those in a better financial position do not want to use these services. More than $93.4 \%$ of respondents do not have housing problems; do not need home or household assistance, or job placement assistance, which clearly shows that members of the surveyed age, despite lesser or greater health complaints are still live an active and almost fully self-sufficient. The only exception that we can find to this is in the case of special services, as $6.5 \%$ of the respondents would need financial advice for investments and savings, $10.8 \%$ would need help with retirement planning, and $13 \%$ would need help with interpreting or filling out official documents.

\section{Conclusion}

The purpose of this study was to survey the population of all settlement types with a questionnaire according to the spatial structure created by the rDSS-index to complement the previous secondary statistical analysis with primary data in order to reveal real socio-economic problems that threaten aging workers, not only in rural but 
also in urban areas. We have partially succeeded in achieving this goal by identifying the most serious challenges facing aging workers. The majority of respondents want to live in better conditions, regardless of educational level, labour market status or financial situation, but many of them do not have the motivation to do so. 58.7\% of the respondents have specific goals and plans for the future and their years of retirement, and this is closely related to their level of education. Every respondent who makes plans for his or her seniority has at least intermediate, but most of them tend to have tertiary education. In addition, it is also clear from the data that the respondents who are in good health set goals for themselves, so that their inactivity in the labour market does not mean a decline but maintenance of their activity. Another important aspect with the progress of age was maintaining health, which includes both physical and mental health. As long as the aging people feel that they are needed and there are people that they can rely on, the process of physical and mental decline is a bearable discomfort. However, the more isolated and ineffective they become, the quicker it will lead to their decline, which will eventually make it indispensable for them to use retirement homes and nursing homes as they become unable to provide for themselves.

On the positive side, many of the respondents have plans for the future, but have few concrete ideas on how to fulfil these. The problem of low-value answers also arises when it comes to meeting needs where the majority of those filled out the questionnaire either do not really need help or do not know how to solve their problems due to lack of awareness. There is no significant difference in terms of territorial distribution, depending on whether the respondents live in a county seat, a district seat or in small villages. Similarly, no significant shift can be detected based on the gender of the respondents. Their level of awareness is much more influenced by their level of education. $45.5 \%$ of those with only primary or vocational qualifications $(21.7 \%$ of all the respondents), regardless of their place of residence, did not have information on the existence of an institution providing social service in their municipality. The financial situation may somewhat obscure this picture, as among the respondents unaware of social services, there were none who reported their financial situation as being problematic, although nearly one-fifth of them said that they live up their total monthly earnings, which could be as high as two hundred thousand HUF. However, the vast majority are capable of making minimal or greater savings; therefore it is likely that they are unaware of the existence of these services, because they do not need them according to their own discretion.

Unlike awareness, the lack of conscious planning for the future is clearly influenced not only by the level of education, but also by other factors. $38.8 \%$ of respondents did not have or did not share their plans when completing the questionnaire. Barely one-third (31.6\%) of these respondents have higher than tertiary education, indicating that more highly qualified individuals may not have long-term plans either or simply did not wish to share them. In fact, $21 \%$ of those who do not have any future plans have a certain amount of pension savings and more than half of them have at least a basic university degree.

However, in addition to sharing more information about their socio-economic situation, highly skilled respondents are much more conscious about planning their 
future and come up with practical solutions to their problems in life. Therefore, we consider it important that in addition to improving access to social services, it is inevitable that a proper information network be set up to make the services available for a wider range of people in need. In addition, changing the current perception of aging is of particular importance. A shift would be needed to draw attention to the fact that aging is a natural process. The older an employee is the more experience they have gained in a given job or jobs, which would be essential for the better preparation of new generations. Aging should therefore be seen as a new socio-economic role that can contribute to the successful integration of entrants into the workplace.

\section{References}

Augustine, E. C. - Dolinting, T. J. (2016): Sustainable Social Services: Human and Nature in Harmony. Procedia - Social and Behavioral Sciences, 224, 15 June 2016, Pages 579-586.

http://www.sciencedirect.com/science/article/pii/S1877042816305286 Accessed: January 15, 2020.

Bakri, N. I. M. - Osman, M. M. - Bachok, S. - Shuid, S. (2016): An Assessment Service Delivery of Social Welfare Department Dealing with Vulnerable and Disadvantages Group in Perak. Procedia - Social and Behavioral Sciences, 222, 23 June 2016, 203-210.

http://www.sciencedirect.com/science/article/pii/S1877042816302221

Accessed: January 15, 2020.

Dobossy, I. - S. Molnár, E. - Virágh, E. (2003): Öregedés és társadalmi környezet.

KSH NKI Mühelytanulmányok 3. sz. Budapest: KSH Népességtudományi

Kutatóintézet. $77-82$.

http://demografia.hu/kiadvanyokonline/index.php/muhelytanulmanyok/article /view/869 Accessed: January 15, 2020.

Fong, K. (2017): Child welfare involvement and contexts of poverty: The role of parental adversities, social networks, and social services. Children and Youth Services Review, 72, January 2017, 5-13.

http://www.sciencedirect.com/science/article/pii/S0190740916303346

Accessed: January 15, 2020.

Hajdu, T. (2015): Tanulmányok a szubjektív jóllét és az anyagi helyzet kapcsolatáról: jövedelem, fogyasztás és egyenlötlenség. PhD-értekezés http://phd.lib.unicorvinus.hu/888/1/Hajdu Tamas.pdf Accessed: January 15, 2020.

Hernandez, D. - Rossel, C. (2015): Inequality and access to social services in Latin America: space-time constraints of child health checkups and prenatal care in Montevideo. Journal of Transport Geography, 44, April 2015, 24-32. http://www.sciencedirect.com/science/article/pii/S0966692315000320 Accessed: January 15, 2020.

Hoványi, G. - Tésits, R. - Alpek, B. L. (2019): Új módszer a társadalmi egyenlőtlenségek területi jellegzetességeinek mérésére a Dél-Dunántúlon. Humán Innovációs Szemle 10, 1, 42-54. 
Jakešová, J. (2015): Assessment of the Needs and Feelings of Depression of Seniors in Residential Social Services: Selected Results. Procedia - Social and Behavioral Sciences, 174, 12 February 2015, Pages 870-877 http://www.sciencedirect.com/science/article/pii/S1877042815007533 Accessed: January 15, 2020.

Jeon, B. - Noguchi, H. - Kwon, S. - Ito, T. - Tamiya, N. (2017): Disability, poverty, and role of the basic livelihood security system on health services utilization among the elderly in South Korea. Social Science \& Medicine, 178, April 2017, Pages 175-183 http://www.sciencedirect.com/science/article/pii/S0277953617301028?np=y \&npKey $=\mathrm{cd} 0 \mathrm{a} 5382554 \mathrm{ee} 22 \mathrm{ef} 24745 \mathrm{~b} 316209 \mathrm{db} 9 \mathrm{f} 396743 \mathrm{e} 2 \mathrm{~d} 83 \mathrm{f} 19 \mathrm{~b} 75 \mathrm{~d} 40 \mathrm{cb} 0$ 4907eb15 Accessed: January 15, 2020.

Majercsik, E. (2004): Idősek a mában. PhD-értekezés. Geriátriai szocio-pszichológiai vizsgálat, az életminőség javításának lehetősége (témavezető: Prof. Dr. Kopp Mária) Semmelweis Egyetem Magatartástudományi Intézet, Budapest. http://semmelweis.hu/wp-content/phd/phd_live/vedes/export/majercsik.d.pdf Accessed: January 15, 2020.

Menachem, S. (2015): Is Social Services Policy Based on Constraints, Ideology or Politics? Procedia - Social and Behavioral Sciences, 209, 3 December 2015, Pages 490-496. http://www.sciencedirect.com/science/article/pii/S1877042815056244 Accessed: January 15, 2020.

Nemeskéri, Zs. - Szellő, J. (2017): Digitális kompetenciák és a pályaorientáció munkaerö-piaci összefüggései a 21. században. Kutátási zárótánulmány http://mek.oszk.hu/16800/16809/16809.pdf

S. Molnár. E. (2004): Az időskorú népesség föbb jellemzöi és életkörülményei http://szolgalatinyugdij.hu/files/az idoskoru nepesseg fobb jellemzoi.pdf Accessed: January 15, 2020.

S. Molnár, E. (2006): Életmód és közérzet az idősödés korában. A tanulmány eredetileg nyomtatásban megjelent: S. Molnár Edit (2004): „Életmód és közérzet az idősödés korában” In Kolosi, T. - Tóth, I. Gy. - Vukovich Gy. (szerk.): Társadalmi riport 2004. Budapest: TÁRKI, Pp. 152-164. http://old.tarki.hu/adatbank-h/kutjel/pdf/a795.pdf Accessed: January 15, 2020.

Szemán, A. - Hegyi, P. - Bakó, Gy. - Molnár, P. (2007): Az élet értelmességének szubjektív megítélése időskorban. Mentálhigiéné és Pszichoszomatika, 8, 4, 309-327. DOI: 10.1556/Mentál.8.2007.4.4 http://real.mtak.hu/58207/1/mental.8.2007.4.4.pdf Accessed: January 15, 2020.

\section{Other sources}

KSH Mikrocenzus (2016): https://www.ksh.hu/docs/hun/xftp/idoszaki/mikrocenzus2016/mikrocenzus_2 016_11.pdf Accessed: January 15, 2020. 